\title{
MONITORING OF WATERS STATUS ON THE AREA OF THE WASTE LANDFILL - CASE STUDY PIŠKORNICA
}

\author{
Jasna Nemčić-Jurec ${ }^{1^{*}}$ \\ ${ }^{1}$ Institute of Public Health of Koprivnica-Križevci County, Trg Tomislava dr. Bardeka 10/10, 48000 \\ Koprivnica, Croatia \\ *E-mail of corresponding author: jasna.nemcic-jurec@zzjz-kkz.hr; jnemcicj@gmail.com
}

\begin{abstract}
The remediation of the municipal waste landfill reduces the harmful effects of inadequately disposed waste in the environment and reduce the risks on human health. The aim of this paper is to evaluate the efficiency of the remediation (2005 to 2012) of waste landfill of Piškornica. Groundwater from piezometers (P2, P3, P4 and P5) at Piškornica and surface water from the Gliboki stream (upstream and downstream) were analyzed, before and after the remediation. The results of the analyzed parameters (KPK, BPK, electroconductivity, iron) showed significant decrease in values ( $p<0.05)$ and up to $82 \%$ (BPK 5 in P5) after remediation. The most significant decrease in the value of the indicators was determined in the P5, which is nearest and downstream from the landfill body. Significant difference $(p<0.05)$ was not found at the upstream and downstream locations of the Gliboki stream basin before and after remediation. The numerical model of the groundwater flow shows that groundwater pollution will not occur even in the worst scenario (the largest possible pumping of $420 \mathrm{l} / \mathrm{s}$ ) of the current capacity of the Ivanščak source. The results contributed to decisions on water management and further monitoring of water plans on landfill area.
\end{abstract}

Keywords: waste landfill, remediation, monitoring of waters, numerical model.

Received: 18.06.2019. / Accepted: 20.11.2019.

Published online: 09.12.2019.

Original scientific paper

\section{INTRODUCTION}

Municipal solid waste (MSW) disposal is a global problem in developing countries and the rise in the urban population in the past few decades point out the necessity to develop environmentally sustainable management system (Hossain et al 2014; Hui Liu et al. 2010; Sumathi et al. 2008). The high production volume of dangerous materials and industrial waste and their impact on the human health and environment, have become one of the most important decisions in urban management. Solid waste management is a difficult task and includes the control of generation, collection, transfer and disposal of solid waste in an environmentally acceptable manner (Barjinder et al. 2014). Landfill is the simplest and cheapest effective method of disposing of solid waste (Hossain et al. 2014; Barjinder et al. 2014). The most landfills are open dumps landfills. Therefore, due to ecological and socioeconomic criteria, it is essential to find an optimal location which has the lowest environmental risk and economically favorable (Danesh et al. 2019). The waste placed in landfills can influence on groundwater quality by infiltration of leachate. Municipal landfill leachate is highly concentrated complex effluents which contain disolved inorganic or organic compounds, heavy metals or other toxic substances (Hui Liu et al. 2010; Barjinder et al. 2014). Environmental pollution from landfills depends on various interconnected factors such as landfill location characteristics, waste amount and type, the amount of precipitation and leachate. Considering these factors, landfills urgently requiring remediation based on multicriteria decision making, in which hazards must be evaluated (Ubavin et al. 2017). Remediation of old landfills with no leachate collection system is demanding and costly operation. It requires control of environment and the landfill body, since the pollutants are still present in the landfilled waste for decades after the site has been closed (Thomas et al. 2007). Most remediation methods involve a wide range of activities that result in social, economic and environmental impacts. It is suggested that natural attenuation is a feasible approach but is demanding and complicated (Thomas et al. 2007), therefore the largest and most obvious impacts (cost and duration) will ussualy be taken into account when selecting an appropriate technology and remediation methods to be used (Harbottle et al. 2008). Landfills may pose serious threat to the both groundwater and surface water quality if incorrectly secured and improperly operated. Groundwater is known as major source of water supply and its contamination is a major heath concern (Longe \& Balogun 2010). Therefore, assesment of groundwater quality and monitoring surface water near municipal landfill site during work and remediation of the landfill reduces the risk to the environment and people health (Longe \& Balogun 2010; Talalaj 2014; Ogundiran \& Afolabi 2008). The risk also depends on local hydrogeology and soil stratigraphy beneath the landfill base and these are important factors in the natural attenuation of leachate constituents in the groundwater body (Longe \& Enekwechi 2007). Groundwater in piezometers close to the landfill is under a strong landfill impact (Talalaj 
2014; Chapuis \& Sabourin 1989; Cherry et al. 1983). Some researces (Cherry et al. 1983) have established networks of different types of devices for multilevel groundwater monitoring and in these way they determined migration of contaminants in groundwater at a landfill (Chapuis \& Sabourin 1989; Cherry et al. 1983). Some devices are particularly well suited for use in aquifers composed of sand or gravel that have little clay and groundwater flow is primarily horizontal (Cherry et al. 1983). Lopes et al. (2012) defined leachate plume and located groundwater monitoring wells using different geophysical technique in order to evaluate groundwater contamination in the surrounding area of a landfill. In general, industrial or municipal waste and agricultural runoff are the most often antropogenic pollution sources. Rivers and streams are also exposed to pollution sources. Therefore it is important to investigate the origin of each surface water quality variable due to land use activities based on spatial water quality assessment using environmetric techniques. The aplication of environmetric methods can reveal meaningful information on the spatial variability of river water quality data (Juahir et al. 2011). The river surface water is greatly exposed to the risk of contamination from leachate unless proper leachate management is carried out. The influence of leachate on river water quality depend on many factors as leachate characteristics, precipitation, surface runoff or applied treatment (Cherry et al. 1983). Improper treatment practise leads to high levels of contaminants in the streams or rivers near the rehabilitated or closed landfills. Some studies (Yusof et al. 2009; Zafar \& Alappat 2011) have shown that chemical analysis of surface waters at corresponding river section which is affected by the presence of landfill surface runoff, is very important part of waste management. In the studies, a series of indicators ( $\mathrm{pH}$, conductivity, $\mathrm{COD}$, total solids, anions, cations, heavy metals, nitrogen anorganic compounds, organic compounds etc.) were investigated with the aim identifying one of the largest sources of environmental pollution, such as a landfill (Yusof et al. 2009; Zafar and Alappat 2011).

The main aim of this paper has been to evaluate the impacts of landfill on groundwater and surface water quality and the efficiency of the remediation of waste landfill of Piškornica (Koprivnica-Križevci county, northwest Croatia) as well. Groundwater from piezometers (P2, P3, P4 and P5) at the location of the landfill and surface water from the Gliboki stream (upstream and downstream from the landfill location) were analyzed, before and after the remediation. Grundwater is the major source of drinking water supply in the study area and its contamination is a major and environmental concern. Therefore, the numerical model (Ackerer et al. 1999) of the groundwater flow and transfer of pollutant was done with aim to show possible influence on the groundwater of the source Ivanščak (public water supply) located 5-6 km from the landfill. The study was carried out in the period from 2002 to 2018 (piezometers) and from 2008 to 2018 (the Gliboki stream) to assess the physical and chemical parameters of groundwater and surface water during all seasons. The remediation was carried out from 2005 to 2012.

\section{MATERIALS AND METHODS}

\subsection{Study area}

The Piškornica landfill is situated in Koprivnički Ivanec ( $\mathrm{x}=5640168.50$ and $\mathrm{y}=5122332.05)$, close to Koprivnica, the largest city of Koprivnica-križevci county. It started operations in the year 1982 and covered an area of about 10 hectares (Figure 1). Between 1982 and 2000 (before remediation), 223000 tonnes of MSW was land filled. Wastes are of different types, ranging from organic to inorganic, hazardous and non-hazardous. Remediation started in 2005 year. The remediation was carried out by constructing the bottom sealing layer and collecting system for leaches and on such arranged plateau, old waste was moving and new-arrived waste was land filled.

The wider area of the location of Piškornica belongs to the low Panonian and Peripanonian area. The layout of surface and groundwater as well as their interconnections are determined by the morphological and hydrogeological features of the wider area of the Piskornica. The waste landfill is located on clustery, mostly aluvial deposits with a lower top layer of clay-dusty material with humus (Duić \& Urumović 2007). Study area belongs to Drava river catchment. The most important tributary of the Drava river on study area is the Gliboki stream, $250 \mathrm{~m}$ away from the landfill.

The mean monthly temperature ranges from $-4{ }^{\circ} \mathrm{C}$ in January to $20^{\circ} \mathrm{C}$ in July. The minimum and maximum annual temperatures are $-26^{\circ} \mathrm{C}$ and $35^{\circ} \mathrm{C}$, respectively. Average rainfall range from 800 to $900 \mathrm{~mm}$. The highest amount of precipitation is during the period from April to July $\left(60\right.$ to $\left.80 \mathrm{~mm} / \mathrm{m}^{3}\right)$. On study area the moderately warm climate predominates (State Hydrometeorological Institute).

At a distance of 5 to $6 \mathrm{~km}$ from the landfill there is the source Ivanščak (public water supply) which supplies about 30000 inhabitants of Koprivnica city and surrounding settlements.

\subsection{Sampling and analysis}

To assess the extent of groundwater contamination, 4 piezometers (P2, P3, P4 and P5) were selected. Positions of piezometers inside landfill are shown on Figure 1. Samples were collected in average 4 time in year during 2002 to 2018. in clean $5000 \mathrm{ml}$ plastic container after the extraction of water (with pump) from a piezometer. The 
water has flowed (before sampling) to ensure the discharge of 5 to 6 volumes of water from the piezometer and up to stabilization of EC of water. Each bottle was labelled according to sampling location while all the samples were preserved at $4^{\circ} \mathrm{C}$ and transported to the laboratory. All the samples were analysed for the physico-chemical parameteres and iron (Table 1).

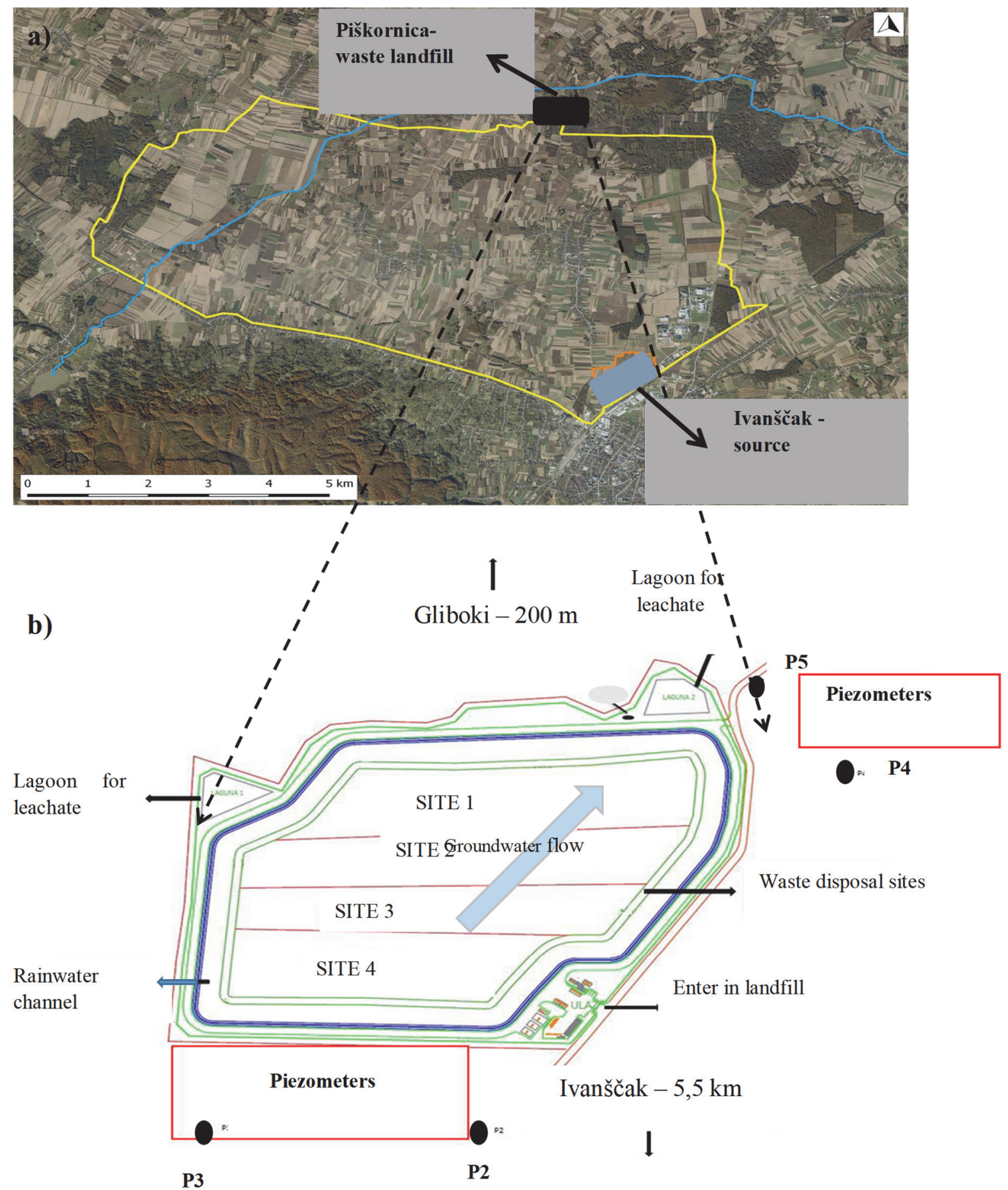

Figure 1. a) Study area - waste landfill Piškornica and source Ivanščak locations b) waste landfill Piškornica - piezometer locations (P2, P3, P4, P5)

Surface water samples from Gliboki stream (Figure 1) were collected from distances of $400 \mathrm{~m}$ upstream and $600 \mathrm{~m}$ downstream from the landfill. Samples were collected with a container at a depth of about $30 \mathrm{~cm}$ below the surface of stream and transferred to a $5000 \mathrm{ml}$ plastic clean container. Each container was labelled according to sampling location and all the samples were preserved at $4{ }^{\circ} \mathrm{C}$ and transported to the laboratory and were analysed for the parameters in Table 1. 
The analysis was done within the next 48 hours which is recommended for better result and in minimizing the quality change. All the samples were analysed according to internationally accepted procedures (Table 1), standard methods (Rice et al. 2012) and Norms.

Table 1. Methods (Norms) used in analysis of physico-chemical parameters of water samples

\begin{tabular}{|c|c|}
\hline PARAMETER & METHOD \\
\hline Chemical oxygen demand (COD) & HRN ISO 15705:2003 \\
\hline Biochemical oxygen demand (BOD 5$)$ & HRN EN 1899-1:2004 \\
\hline Electroconductivity (EC) & HRN EN 10523:2012 \\
\hline Iron (Fe) & HRN ISO 8288:1995 \\
\hline
\end{tabular}

\section{RESULTS AND DISSCUSION}

\subsection{Groundwater quality}

Analytical results of physico-chemical characteristics of groundwater samples from piezometers include general indicators of pollution as electrical conductivity (EC), chemical oxygen demand (COD), biochemical oxygen demand $\left(\mathrm{BOD}_{5}\right)$ and iron $(\mathrm{Fe})$. The results of monitoring of groundwater samples are presented at Figure $\mathbf{2 a}, \mathbf{2 b}, \mathbf{2 c}$ and $\mathbf{2 d}$.

Electrical conductivity (Figure 2a) in P2, P3 and P4 was high but below standard limits. High EC is a symbol of high ionic load and indicates that organic and inorganic matter has washed into groundwater on that location. Groundwater on P5 location is highly contaminated by organic and inorganic matters (Hossain et al. 2014) and it has been observed that value is higher than standard limits of $2500 \mu \mathrm{S} / \mathrm{cm}$ (National Newspaper 125 2017). After remediation, the trend of decrease of the conductivity value in Piezometer P5 (Figure 2a) has been observed. This suggests a reduced impact of leachate and drainage of the contents of the landfill into the environment or groundwater. It is assumed that the decrease of the conductivity is a result of the remediation of the landfill (Ubavin et al. 2017; Talalaj 2014).

Chemical oxygen demand and biochemical oxygen demand indicate the presence of inorganic or organic pollutants. According to the results (Figure 2b) the COD value is the highest on piezometer P5, then piezometer P2 while lower values are determined in piezometers P3 and P4. Some scientists (Lopes et al. 2012) found low $\mathrm{BOD}_{5}$ values at groundwater in the surrounding area of a landfill, however, COD values were determined at 40 times higher than the concentration of $\mathrm{BOD}_{5}$. It is also visible (Figure 2c) that the $\mathrm{BOD}_{5}$ values are also the highest in piezometer P5. The figures also show that the values for both parameters decreased, indicating the effect of landfill remediation (Barjinder et al. 2014).

Heavy metals are often present on landfill sites in leachate. Their concentrations depend on the composition of the waste and on the stage of waste construction (Talalaj 2014; Ogundiran \& Afolabi, 2008). Also, the concentration of metal in groundwater depends on the geological composition of the soil (the natural origin of metals). Considering the significant concentrations of iron of natural origin (Duić \& Urumović, 2007) found in the study area, the concentrations were monitored at the piezometers of the landfill. Iron is most commonly found in groundwater in the form of $\mathrm{Fe}^{2+}$ and and is bound in organic molecules. It indicating also the possibility of binding of $\mathrm{Fe}^{2+}$ to organic matter derived from the landfill (Yusof et al. 2009). Under anaerobic conditions, iron is dissolved, which may result in an increased concentration of iron in the groundwater. On the study area the alluvial deposits is rich in iron salts which can contribute to increased concentration in groundwater. The results of the movement of iron concentrations are shown in Figure 2d. The highest concentrations were recorded in the period from 2004 to 2008 and thereafter a significant decrease in concentration in all piezometers is visible (Hossain et al. 2014; Talalaj 2014).

According to the results of the statistical analysis (t-test) of measured groundwater indicators before (V1) and after (V2) landfill remediation, average values has shown (Table 2) a statistically significant difference $(p=0.05$; $95 \%$ ). It has been shown that values before remediation are significantly higher than the values after remediation, which indicates the impact of the observed factor (remediation) on groundwater quality. The differences are particularly visible in piezometer $\mathrm{P} 5$ where for $\mathrm{EC}, \mathrm{COD}$ and $\mathrm{BOD}_{5}$ values $\mathrm{V} 1$ are greater than V2. COD and $\mathrm{BOD}_{5}$ values have shown a statistically significant difference in piezometer P2 indicating groundwater contamination before remediation at that location (Ubavin et al. 2017). The mean iron concentration have not changed significantly after the landfill remediation pointing out to the natural sources of iron on study area (Duić \& Urumović 2007), however, higher concentration variability is visible before landfill remediation.

The relationship measured variables (indicators) between the individual piezometers was estimated by the analysis of variance (ANOVA). The results of the mean values of the measurement of all indicators before (V1) and after (V2) remediation used for ANOVA test are shown in Table 2. If the variability between the groups was 
greater than the variability within the group, it was concluded that the differences are statistically significant (F> Fcrit.; $\mathrm{p}=0.05$ ).

According to the results of the $\mathrm{EC}$, by comparing before $(\mathrm{F}=71$, Fcrit $=2.69)$ and after $(\mathrm{F}=8.57$, Fcrit $=2.81)$ the remediation of the landfill, significant changes were found only at location P5. However, the ANOVA test found that the values for P5, despite the decrease after remediation, are still higher than other locations (P2 to P4).

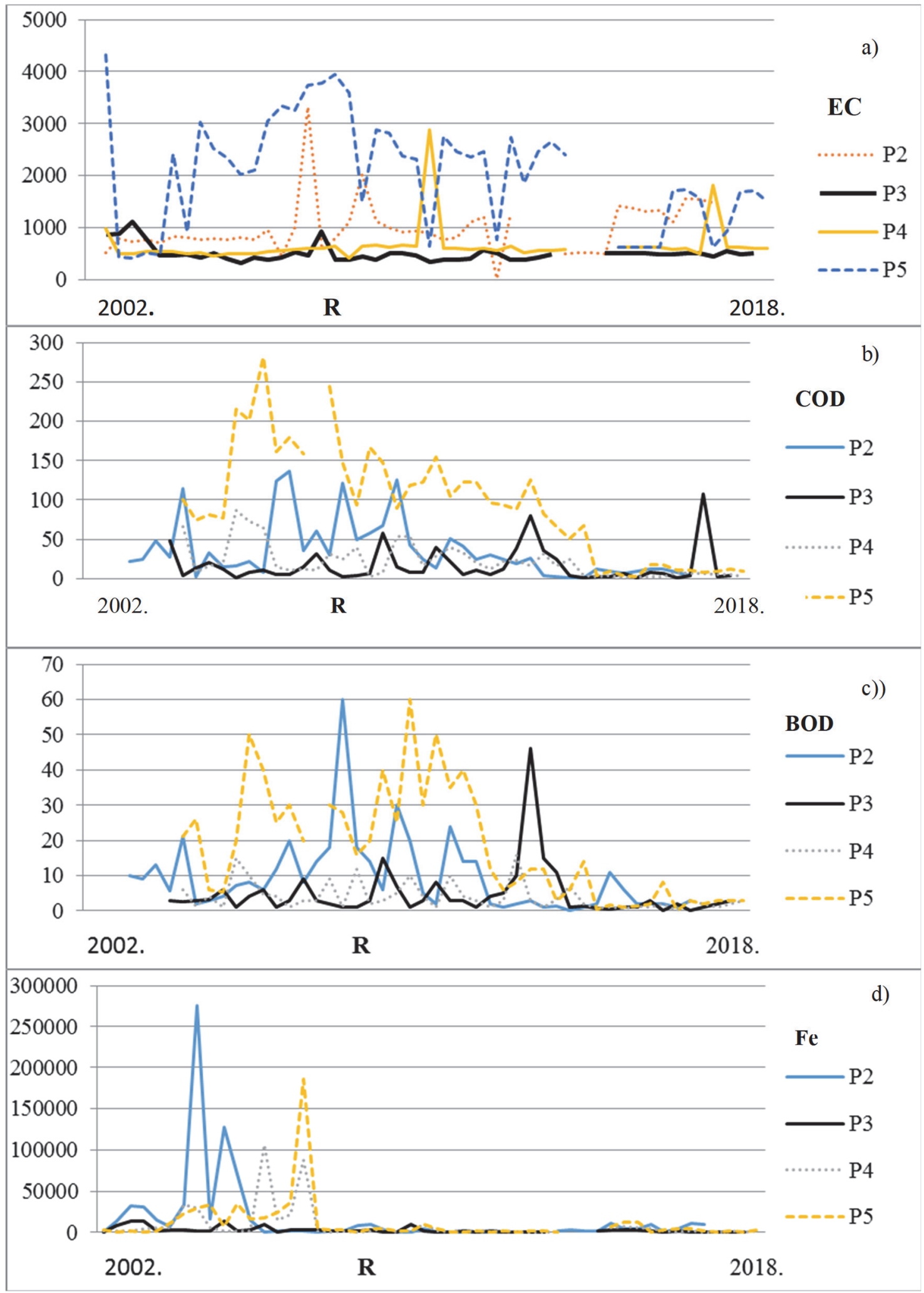

Figure 2. Monitoring of groundwater (piezometers) quality; R-the beginning of remediation a) electrical conductivity (EC); b) chemical oxygen demand (COD; c) biochemical oxygen demand (BOD); d) iron $(\mathrm{Fe})$ 
According to the ANOVA result test, COD values at P5 location are significantly higher than those at other locations (P2 to $\mathrm{P} 4)$. However, the differences between the piezometers after remediation $(\mathrm{F}=5.2, \mathrm{Fcrit}=2.76)$ are less than the difference between locations prior to remediation $(\mathrm{F}=54.5$, Fcrit $=2.70)$.

Analysis of variance has shown that there are significant differences in $\mathrm{BOD}_{5}$ values for individual locations before landfill remediation $(\mathrm{F}=33.9$, Fcrit $=2.70)$ due to high $\mathrm{BOD}_{5}$ values at $\mathrm{P} 5$ location. After the landfill remediation, this value at $\mathrm{P} 5$ location significantly decreased, so the variance of analysis results has shown that there are no significant differences $(\mathrm{F}=0.68$, Fcrit $=2.77)$ among the mean $\mathrm{BOD}_{5}$ values.

ANOVA results also showed that there were no significant differences before $(\mathrm{F}=1.73, \mathrm{Fcrit}=2.69)$ and after $(\mathrm{F}=1.68$, Fcrit $=2.81)$ remediation of landfill among the mean values of the iron obtained at piezometers $\mathrm{P} 2$ to $\mathrm{P} 5$.

The results of the mean values of the measurement of all indicators before (V1) and after (V2) remediation used for ANOVA test are shown in Table 2.

Table 2. Indicator values before and after remediation at locations of piezometers P2, P3, P4, P5 (t-test, $95 \%$ significance level; N-number of samples)

\begin{tabular}{|c|c|c|c|c|c|}
\hline INDICATOR & PIEZOMETER & $\begin{array}{c}\mathbf{V 1} \\
\mathbf{N}=\mathbf{2 3}-\mathbf{2 7} \\
\end{array}$ & $\begin{array}{c}V 2 \\
N=12-15\end{array}$ & T-EKSP. & $\begin{array}{l}\text { RELATION } \\
\text { V1 AND V2 }\end{array}$ \\
\hline \multirow{4}{*}{$\mathrm{EC}(\mu \mathrm{S} / \mathrm{cm})$} & P2 & 949 & 923 & 0.15 & $\mathrm{~V} 1=\mathrm{V} 2$ \\
\hline & P3 & 515 & 472 & 1.13 & $\mathrm{~V} 1=\mathrm{V} 2$ \\
\hline & $\mathrm{P} 4$ & 649 & 682 & 0.24 & $\mathrm{~V} 1=\mathrm{V} 2$ \\
\hline & P5 & 2330 & 1454 & 2.45 & $\mathrm{~V} 1>\mathrm{V} 2$ \\
\hline \multirow{4}{*}{$\mathrm{COD}(\mathrm{mg} / \mathrm{l})$} & $\mathrm{P} 2$ & 50 & 17 & 3.56 & $\mathrm{~V} 1>\mathrm{V} 2$ \\
\hline & $\mathrm{P} 3$ & 15 & 15 & 0.04 & $\mathrm{~V} 1=\mathrm{V} 2$ \\
\hline & $\mathrm{P} 4$ & 31 & 11 & 3.65 & $\mathrm{~V} 1>\mathrm{V} 2$ \\
\hline & P5 & 142 & 43 & 5.93 & $\mathrm{~V} 1>\mathrm{V} 2$ \\
\hline \multirow{4}{*}{ BOD5 (mg/l) } & $\mathrm{P} 2$ & 13 & 6 & 2.44 & $\mathrm{~V} 1>\mathrm{V} 2$ \\
\hline & P3 & 4 & 7 & 1.15 & $\mathrm{~V} 1=\mathrm{V} 2$ \\
\hline & $\mathrm{P} 4$ & 5 & 3 & 1.47 & $\mathrm{~V} 1=\mathrm{V} 2$ \\
\hline & P5 & 29 & 5 & 7.55 & $\mathrm{~V} 1>\mathrm{V} 2$ \\
\hline \multirow{4}{*}{$\mathrm{Fe}(\mu \mathrm{g} / \mathrm{l})$} & $\mathrm{P} 2$ & 25191 & 3548 & 1.96 & $\mathrm{~V} 1=\mathrm{V} 2$ \\
\hline & $\mathrm{P} 3$ & 2993 & 1579 & 1.99 & $\mathrm{~V} 1=\mathrm{V} 2$ \\
\hline & P4 & 11676 & 2682 & 2.02 & $\mathrm{~V} 1=\mathrm{V} 2$ \\
\hline & P5 & 15292 & 4354 & 1.77 & $\mathrm{~V} 1=\mathrm{V} 2$ \\
\hline
\end{tabular}

V1-before remediation; V2-after remediation

\subsection{Surface water quality}

For monitoring of the surface water quality of the Gliboki stream, general pollution indicators have been selected as EC, COD and $\mathrm{BOD}_{5}$ (Juahir et al. 2011). Concentration trends during the monitoring are shown in Figure 3a, 3b and 3c. Valuable indicators in the Gliboki stream indicate on the variability, but there is no significant difference of values between upstream and downstream from the landfill site. However, Figure 3c shows a high concentration of $\mathrm{BOD}_{5}$ of $9 \mathrm{mg} / \mathrm{l}$ in the Gliboki downstream of the landfill (September 2012.). It is assumed to be related to the uncontrolled discharge of untreated waste water (organic pollution) from agriculture, in the environment. The results of the t-tests for the mean values of EC, COD and $\mathrm{BOD}_{5}$ obtained by examination of the surface water quality from the Gliboki stream are shown in Table 3. According to the results, the difference in the values of the measured parameters, before and after remediation of the landfill, is not obtained, except for $\mathrm{G} 2$ (downstream) where $\mathrm{BOD}_{5}$ has shown decrease after remediation. Given that the values decreased upstream and downstream from the landfill, it is assumed that $\mathrm{BOD}_{5}$ decrease is not affected by the landfill but depends on a number of other environmental factors on the study area (Danesh et al. 2019; Zafar \& Alappat 2011).

The results showed that the values of measured indicators were similar upstream and downstream and no statistically significant difference $(\mathrm{p}=0.05)$ was demonstrated. It follows that the landfill does not affect the quality of surface water from the Gliboki stream. The results of other scientists (Hui Liu et al. 2010) have also shown that the proximity of the landfill is not necessarily a risk for surface water pollution. It is important to take into account all environmental risk factors such as agriculture, industry or natural (Danesh et al. 2019; Longe \& Balogun 2010).

\subsection{Evaluation of the landfill impact on the source Ivanščak}

The location of the Ivanščak source is shown in Figure 1. The source is located about $5.5 \mathrm{~km}$ from the landfill and has a significant influence on the hydrodynamics of the groundwater flow. Excessive pumping of groundwater could cause a direct connection between the source and the landfill. The existing exploitation of drinking water has not shown the impact of landfill on the quality of drinking water from the source. However, due to the importance of the source on study area, the need for a greater amount of water and increased pumping capacity in the future can be expected. Therefore, several scenarios (S1-S5) of pumping were analyzed in numerical models: 

S1 $Q=0\left(\mathrm{~m}^{3} / \mathrm{s}\right)$
- no pumping;
S2 $Q=100\left(\mathrm{~m}^{3} / \mathrm{s}\right)$
S3 Q $=200\left(\mathrm{~m}^{3} / \mathrm{s}\right)$
- corresponds to the current average pumping;
S4 Q $=420\left(\mathrm{~m}^{3} / \mathrm{s}\right)$
- corresponds to the current maximum pumping;
S5 $\mathrm{Q}=600\left(\mathrm{~m}^{3} / \mathrm{s}\right)$
- corresponds to the current maximum with regard to the pumping capacity;
- corresponds to the pumping that would cause a direct hydrodynamic connection between the source and the landfill Piškornica.

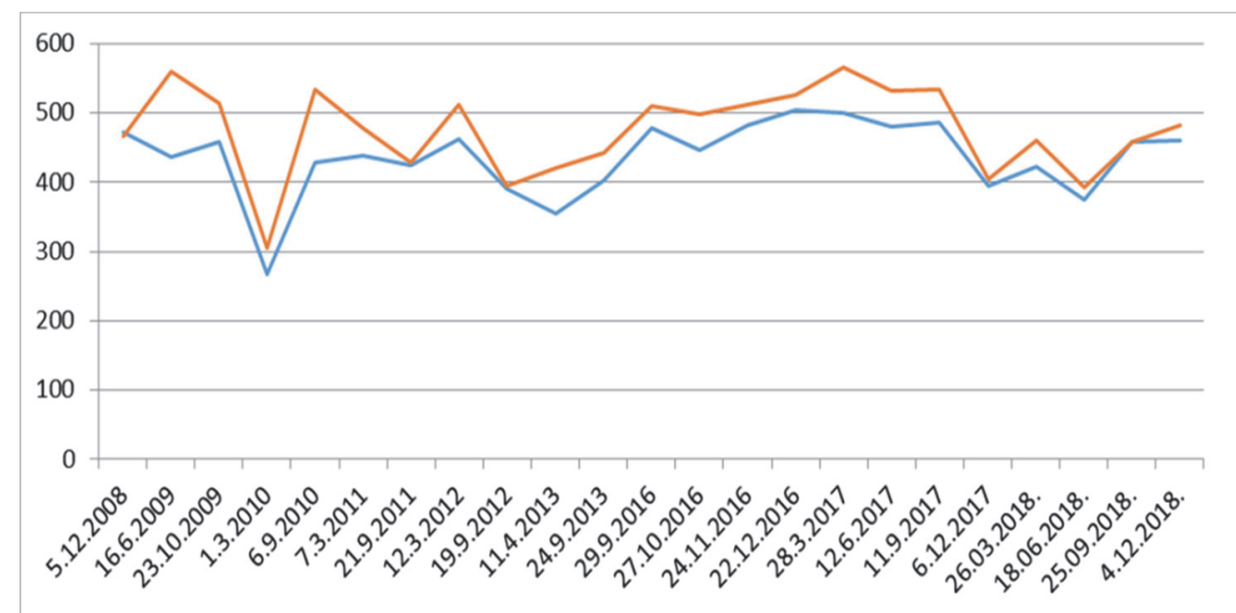

a)

EC
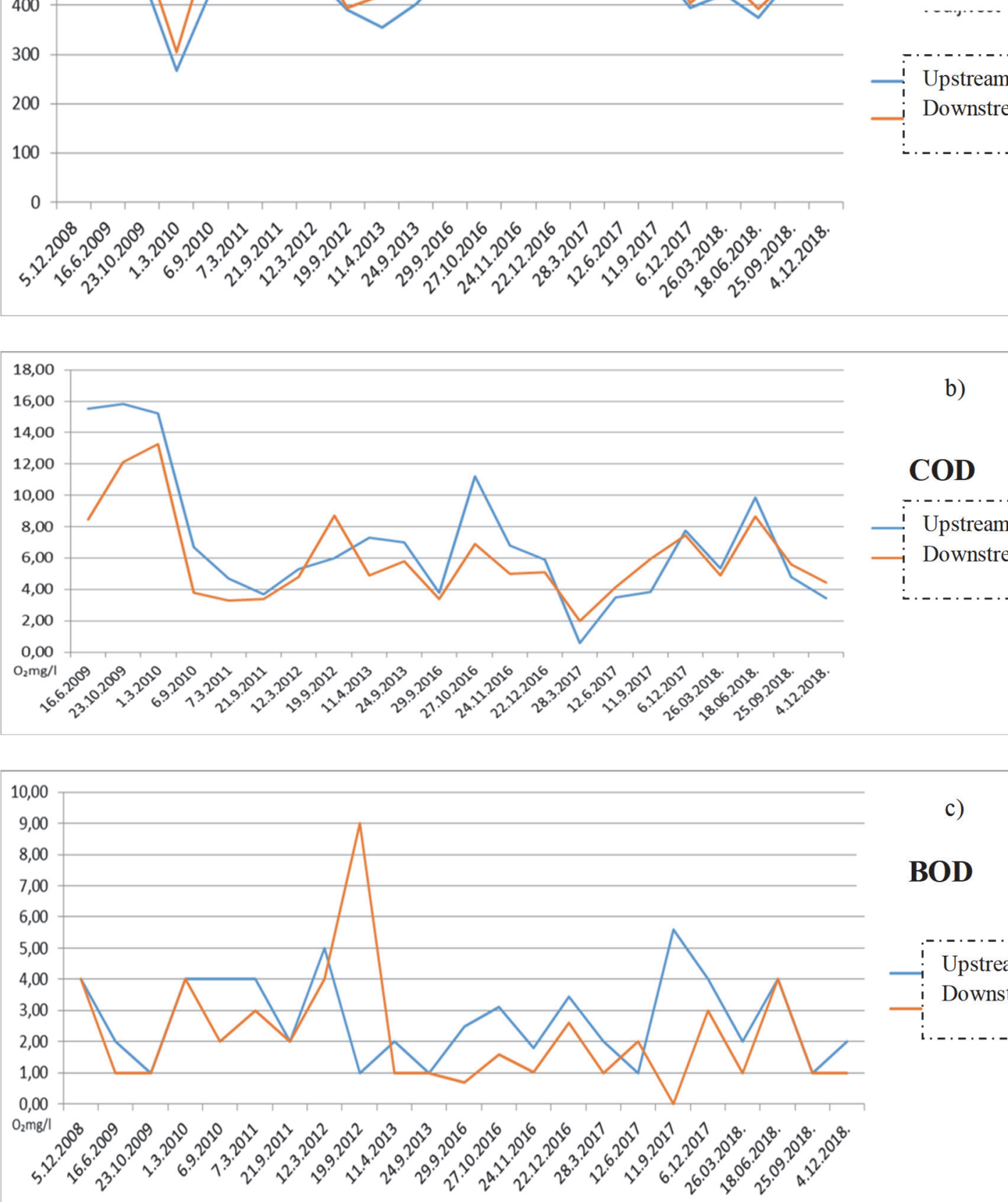

c)

\section{BOD}

Figure 3. Monitoring of surface water quality: a) electrical conductivity (EC); b) chemical oxygen demand (COD); c) biochemical oxygen demand (BOD); P-Pustakovec, Đ-Đelekovec 


\subsection{Numerical models of surface water and transmission of contaminants}

Numerical models were used to show the transmission of the contaminants at a certain pumping capacity (Welty \& Gelhar 1992). The most important and interesting scenarios are S3 and S5. The hydrodynamics of the flow of water at $200 \mathrm{~L} / \mathrm{s}$ (S3) is shown at Figure 4. According to the results, the groundwater flow is not directed to the source and potential contaminants do not affect the water quality at the source. The models show that in all other scenarios (S1, S2, S4) a hydrodynamic connection between the landfill and the source is also not possible. It is estimated that under such conditions of pumping (discharge) it is not possible to transfer contaminants from the landfill to the source (Longe \& Balogun 2010) Under the worst conditions shown for scenario S5 at pumping 600 1/s (Figure 5), groundwater flow indicates a hydrodynamic connection between the landfill and source. However, this capacity of pumping is not possible currently, indicating that the landfill is not a risk for groundwater quality at the Ivanščak source in the near future. It is assumed that a relatively large distance between landfills and sources and environmental factors contributes to good water quality (Longe \& Balogun 2010).

Table 3. The difference between the value of the indicators measured before (V1) and after (V2) landfill remediation on the Gliboki stream

\begin{tabular}{|c|c|c|c|c|c|}
\hline \multirow{2}{*}{ INDICATOR } & $\begin{array}{c}\text { GLIBOKI } \\
\text { STREAM }\end{array}$ & $\begin{array}{c}\text { V1 } \\
\mathbf{N = 9}\end{array}$ & $\begin{array}{c}\text { V2 } \\
\mathbf{N = 1 3}\end{array}$ & T-EKSP. & $\begin{array}{c}\text { RELATION } \\
\text { V1 AND V2 }\end{array}$ \\
\hline \multirow{2}{*}{$\mathrm{EC}(\mu \mathrm{S} / \mathrm{cm})$} & $\mathrm{G} 1$ & 420 & 445 & 1.05 & $\mathrm{~V} 1=\mathrm{V} 2$ \\
\cline { 2 - 6 } & $\mathrm{G} 2$ & 466 & 481 & 0.54 & $\mathrm{~V} 1=\mathrm{V} 2$ \\
\hline \multirow{2}{*}{$\mathrm{COD}(\mathrm{mg} / \mathrm{l})$} & $\mathrm{G} 1$ & 10 & 6 & 1.97 & $\mathrm{~V} 1=\mathrm{V} 2$ \\
\cline { 2 - 6 } & $\mathrm{G} 2$ & 9 & 5 & 1.67 & $\mathrm{~V} 1=\mathrm{V} 2$ \\
\hline \multirow{2}{*}{$\mathrm{BOD} 5(\mathrm{mg} / \mathrm{l})$} & $\mathrm{G} 1$ & 3 & 3 & 0.68 & $\mathrm{~V} 1=\mathrm{V} 2$ \\
\cline { 2 - 6 } & $\mathrm{G} 2$ & 3 & 2 & 2.07 & $\mathrm{~V} 1=\mathrm{V} 2$ \\
\hline
\end{tabular}

G1-upstream; G2-downstream

Table 4. The difference between the value of the indicators measured upstream $(\mathrm{G} 1)$ and downstream $(\mathrm{G} 2)$ of the Gliboki

\begin{tabular}{|c|c|c|c|c|c|}
\hline \multirow{2}{*}{ INDICATOR } & $\begin{array}{c}\text { GLIBOKI } \\
\text { STREAM }\end{array}$ & $\mathbf{G 1}$ & $\mathbf{G 2}$ & T-EKSP. & $\begin{array}{c}\text { RELATION } \\
\text { G1 AND G2 }\end{array}$ \\
\hline \multirow{2}{*}{$\mathrm{EC}(\mu \mathrm{S} / \mathrm{cm})$} & $\mathrm{V} 1$ & 420 & 466 & 1.37 & $\mathrm{G} 1=\mathrm{G} 2$ \\
\cline { 2 - 6 } & $\mathrm{V} 2$ & 445 & 481 & 1.77 & $\mathrm{G} 1=\mathrm{G} 2$ \\
\hline \multirow{2}{*}{$\mathrm{COD}(\mathrm{mg} / \mathrm{l})$} & $\mathrm{V} 1$ & 10 & 9 & 0.48 & $\mathrm{G} 1=\mathrm{G} 2$ \\
\cline { 2 - 6 } & $\mathrm{V} 2$ & 6 & 5 & 0.65 & $\mathrm{G} 1=\mathrm{G} 2$ \\
\hline \multirow{2}{*}{$\mathrm{BOD} 5(\mathrm{mg} / \mathrm{l})$} & $\mathrm{V} 1$ & 3 & 3 & 0.68 & $\mathrm{G} 1=\mathrm{G} 2$ \\
\cline { 2 - 6 } & $\mathrm{V} 2$ & 3 & 2 & 2.12 & $\mathrm{G} 1=\mathrm{G} 2$ \\
\hline
\end{tabular}

V1-before remediation; V2-after remediation

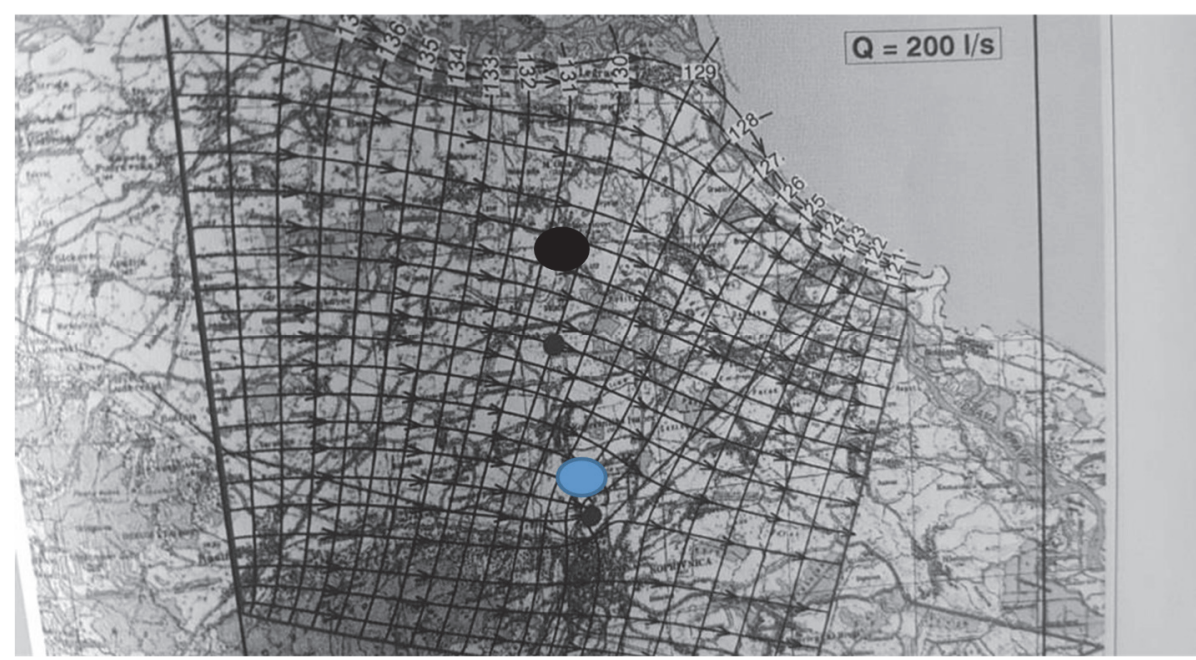

(O - Piškornica location; O - Ivanščak location)

Figure 4. Scenario (S3) of hydrodynamics of the water flow (pumping capacity $Q=200$ 1/s) 


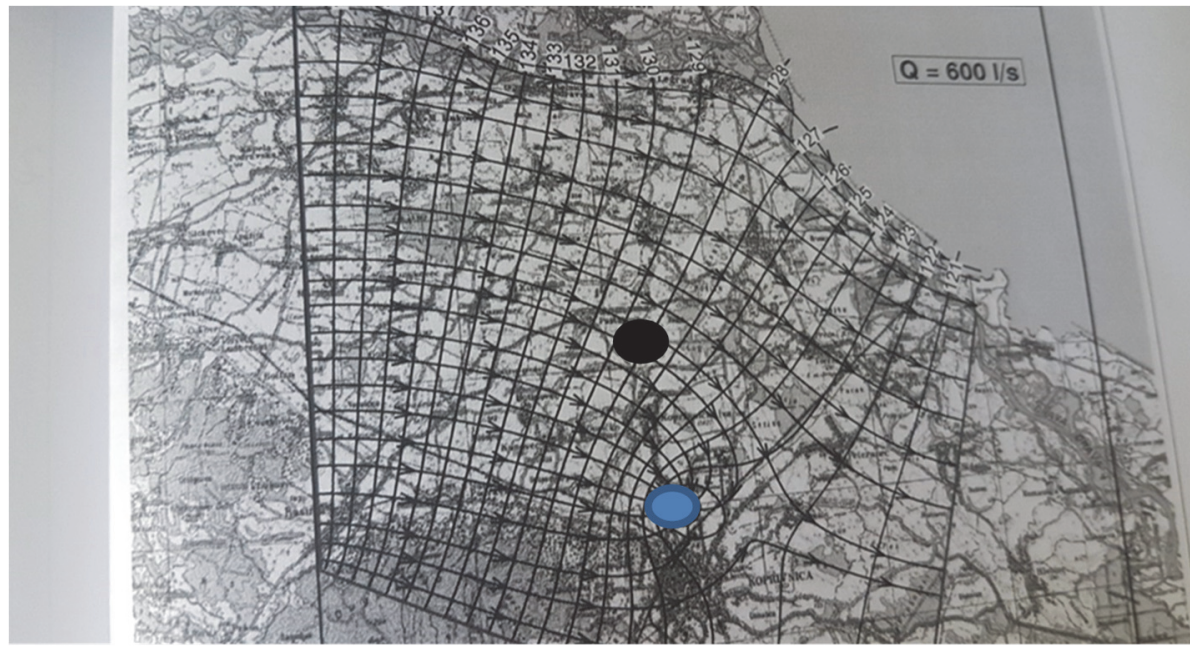

(O - Piškornica location; O - Ivanščak location)

Figure 5. Scenario (S5) of hydrodynamics of the water flow (pumping capacity $Q=6001 / \mathrm{s}$ )

\section{CONCLUSIONS}

Municipal landfills are considered a big risk to their surrounding urban environment. They are the source of pollution especially for groundwater and surface waters. From the study it has been observed that improper practices of solid waste management impact on the groundwater. However, landfill remediation contributed to improving the quality of groundwater from individual piezometers at the landfill site. After the remediation, the value of the indicators decreased in piezometer P5 which is located downstream of the landfill. It is due to the transfer of contaminants to P5 and the impact of improper disposal of waste to groundwater. Examination of surface water of the Gliboki stream near the landfill has not confirmed contamination from the landfill. Pollution has been observed in the upstream and downstream of the landfill, pointing to other sources of environmental pollution. Given the location of the source Ivanščak (public water supply) near the landfill, the mathematical model estimates that the landfill has no effect on groundwater quality from the source. It is concluded that the landfill distance from the source and the groundwater flow direction additionally ensures a reduction of the groundwater quality risk in the near future. The results contributed to decisions on water management and it is suggested that the local government and the management of the landfill corporation should take necessary initiatives for the monitoring of groundwater and surface water quality and that ensure quality water from the public water supply.

\section{REFERENCES}

Ackerer P, Younes A, Mose R (1999) Modeling variable density flow and solute transport in porous medium: 1. Numarical model and verification. Transp Porous Media 35(3), 345-373.

Barjinder B, Saini MS, Jha MK (2014) Assessment of municipal solid waste landfill leachate treatment efficiency by leachate pollution index. Int J Innov Res Sci, Eng Technol 3, 8447-8454.

Chapuis RP, Sabourin L (1989) Effects of installation of piezometers and wells on groundwater characteristics and measurements. Can Geotech J 26(4), 604-613.

Cherry JA, Gillham RW, Anderson EG, Johnson PE (1983) Migration of contaminants in groundwater at a landfill: a case study: 2.groundwater monitoring devices. J Hydrol 63(1-2), 31-49.

Danesh G, Monavari SM, Omrani GA, Karbasi A, Farsad F (2019) Compilation of a model for hazardous waste disposal site selection using GIS-based multi-purpose decision-making models. Environ Monit Assess 191, 122.

Duić Ž, Urumović K (2007) Influence of legrad threshold structure on hydrogeological characteristics in Koprivnica area. In: Rudarsko-geološko-naftni zbornik 19, Zagreb, HR, pp. 1-10.

Harbottle MJ, Al-Tabba A, Evans CW (2008) Sustainability of land remediation. Part 1: overall analysis. In: Proceedings of the ICE-geotechnical engineering 161(2), pp. 75-92.

Hossain ML, Satyajit RD, Hossain MK (2014) Impact of landfill leachate on surface and groundwater quality. J Environ Sci Technol 7, 337-346.

Juahir H, Zain SM, Yusoff MK, Hanidza TI, Armi AS, Toriman ME, Mokhtar M (2011) Spatial water quality assessment of Langat river basin (Malaysia) using environmetric techniques. Environ Monit Assess 173 (1-4), 625-641.

Liu H, Liang Y, Zhang D, Wang C, Liang H, Cai H (2010) Impact of MSW landfill on the environmental contamintaion of phthalate esters. Waste Manage 30, 1569-1576.

Longe EO, Enekwechi LO (2007) Investigation on potential groundwater impacts and influence of local hydrogeology on natural attenuation of leachate at a municipal landfill. Int J Envir Sci \& Technol 4(1), 133-140. 
Longe EO, Balogun MR (2010) Groundwater quality assessment near a minicipal landfill, Lagos, Nigeria. Res J Applied Sci, Eng Technol 2(1), 39-44.

Lopes DD, Silva SMCP, Fernandes F, Teixeira RS, Celligoi A, Dall ALH (2012) Geophysical technique and groundwater monitoring to detect leachate contamination in the surrounding area of a landfill-Londrina (PRBrazil). J Environ Manage 113, 481-487.

National Newspaper 125 (2017) Regulation about the parameters of complience, methods of analysis, monitoring and plans of security of water for human consumption and the way of keeping a register of legal entities performing the activity of public water supply, Zagreb, Croatia.

Ogundiran OO, Afolabi TA (2008) Assessment of the physicochemical parameters and heavy metals toxicity of leachates from municipal solid waste open dumpsite. Int J Environ Sci \& Technol 5(2), 243-250.

Rice EW, Baird RB, Eaton AD, Clesceri LS (2012) Standard methods for the examination of water and wastewater, 22nd edition, Washington, USA: American Public Health Association press

Sumathi VR, Natesan U, Sarkar C (2008) GIS-based approach for optimized siting of municipal solid waste landfill. Waste Manage 28, 2146-2160.

Talalaj IA (2014) Assessment of groundwater quality near the landfill site using the modified water quality index. Environ Monit Assess 186 (6), 3673-3682.

Thomas H, Christensen H, Bjerg PL, Kjeldsen P (2007) Natural attenuation: a feasible approach to remediation of groundwater pollution at landfills. Groundwater Monit \& Remed 20 (1), 69-77.

Ubavin D, Agarski B, Maodus N, Stanisavljević N, Budak I (2017) A model for prioritizing landfills for remediation and closure: a case study in Serbia. Integr Environ Assess Manage 14, 105-119.

Yusof N, Haraguchi A, Hassan MA, Othman MR, Wakisaka M, Shirai Y (2009) Measuring organic carbon, nutrients, and heavy metals in rivers receiving leachate from controlled and uncontrolled municipal solid waste (MSW) landfills. Waste Menage 29, 2666-2680.

Zafar M, Alappat BJ (2011) Landfill surface runoff and its effect on water quality on river Yamuna. J Environ Sci Health, part A 39 (2), 375-384.

Welty C, Gelhar LW (1992) Simulation of large-scale transport of a variable density and viscosity fluids using a stochastical mean model. Water Res Res 28, 815-827. 